\title{
KEDUDUKAN KEPALA DESA SEBAGAI HAKIM PERDAMAIAN
}

Samuel Dharma Putra Nainggolan

Fakultas Hukum Universitas Airlangga Surabaya

Email: snainggolan43@gmail.com

\begin{abstract}
The rural population is a basic capital for national development, owned by the people and the Indonesian nation. In the constitutional structure of the Republic of Indonesia, the Village has developed in various forms and is obliged to be protected and empowered to be strong, advanced, and democratic and democratic so as to carry out governance and development towards a just, prosperous and prosperous society. The involvement of the Village Head in resolving conflicts within rural communities has made the writer interested in studying the nature of cases out of court settlement by the Village Head against the village community and the reformulation of legal policies in implementing the nature of the settlement of a non-court problem. The approach used in this research is statute approach, historical approach, and conceptual approach, and case approach. The results of this study states that solving a problem that occurs in the village by placing the Village Head as a peace judge is a form of discretion / policy of the executive in order to realize public service for the community. In other words because it is a discretion, it certainly follows the laws and regulations that state the limits of it.
\end{abstract}

Keywords: Village, Village Head, Peace Judge.

\section{Pendahuluan}

Kenyataan dewasa ini menunjukkan bahwa bagian terbesar warga masyarakat Indonesia masih tinggal di daerah pedesaan. Dengan demikian dapat dikatakan, penduduk daerah pedesaan merupakan suatu modal dasar bagi pembangunan nasional, yang dimiliki oleh rakyat dan Bangsa Indonesia. Jumlah penduduk pedesaan yanng sedemikian banyak itu apabila dapat dibina dengan baik, dapat menjadi tenaga kerja yang efektif bagi berbagai kegiatan pembangunan di segala bidang kehidupan masyarakat. Sejak dahulu, potensi yang ada di daerah pedesaan Indonesia telah diakui dan bahkan dikelola untuk maksud-maksud tertentu. Pada zaman pra kemerdekaan, secara yuridis formal wilayah atau daerah pedesaan diatur dengan Staatblaad Tahun 1919 Nomor 13, dimana Staatblaad Nomor 212 Tahun 1907 terkait dengan pemilihan Kepala Desa. Dalam hal ini diketahui bahwa sejak jaman pra kemerdekaan, desa memiliki Pemerintahannya sendiri sebagai bagian yang utuh dalam Negara Kesatuan Republik Indonesia setelah merdeka.

Pemerintahan Desa, diakomodir dalam Pasal 18B ayat (2) Undang-Undang Dasar Negara Republik Indonesia Tahun 1945 yang menyatakan: "Negara mengakui dan menghormati kesatuan-kesatuan masyarakat hukum adat beserta hak-hak tradisionalnya 
sepanjang masih hidup dan sesuai dengan perkembangan masyarakat dan prinsip Negara Kesatuan Republik Indonesia, yang diatur dengan undang-undang. Dari pemahaman Pasal 18 B ayat (2) UUD NRI 1945 tersebut bahwa desa diartikan bukan saja sebagai kesatuan masyarakat hukum adat, tetapi juga sebagai hierarkhi pemerintahan yang terendah dalam Negara Kesatuan Republik Indonesia”, disamping itu jelas bahwasanya desa yang pemerintahannya berdasarkan hak asal-usul dan adat istiadat tetap dihormati dan diakui dalam bingkai besar negara bangsa (nation state) yaitu Negara Kesatuan Republik Indonesia.

Desa terasa begitu penting, karena di desa masih digenggamnya hak asal-usul dan hak tradisional (hukum adat) dalam mengatur dan mengurus kepentingan masyarakat setempat dan berperan mewujudkan cita-cita kemerdekaan berdasarkan UUD NRI 1945. Dalam struktur ketatanegaraan Republik Indonesia, Desa telah berkembang dalam berbagai bentuk dan wajib untuk dilindungi dan diberdayakan agar menjadi kuat, maju, dan mandiriserta demokratis sehingga dapat melaksanakan pemerintahan dan pembangunan menuju masyarakat yang adil, makmur, dan sejahtera. Hal ini sejalan dengan upaya mewujudkan tata pemerintahan yang baik (Good Governance) khususnya di pemerintahan Desa.
Merujuk pada konsep negara hukum Pancasila yang bertujuan menciptakan keadilan sosial bagi seluruh rakyatnya. Selain dibutuhkan peran serta gotong royong dari rakyatnya dengan adanya konsep Partisipatory Democracy, ${ }^{1}$ maka Pemerintah sebagai organ/badan yang bertanggung jawab secara langsung dalam pelaksanaan tugas dan fungsinya berdasar amanat konstitusi menjalankan pemerintahan. Mengenai konsep keadilan sendiri sebagai sarana untuk mencapai suatu kesejahteraan sosial, John Rawls memberikan pemahaman mengenai konsep keadilan itu sendiri, keadilan diperlukan adanya kesamaan pandangan dan kesepakatan dari berbagai unsur masyarakat yang terlibat, demi terwujudnya keadilan sosial (social justice) dan juga keadilan hukum (legal justice) yang dilandasi dengan itikad baik untuk melaksanakan prinsip keadilan hukum tersebut. $^{2}$

Studi keadilan merupakan hal yang utama, sebab keadilan adalah salah satu tujuan hukum, bahkan ada yang menyatakan sebagai tujuan utamanya. ${ }^{3}$ Teori tentang keadilan sangat terkait dengan filsafat hukum sebagaimana disampaikan oleh E. Utrecht

\footnotetext{
${ }^{1}$ Ashiddiqie. J. (2015). Pengantar Ilmu Hukum Tata Negara, Jakarta : Raja Grafindo. Hlm 117.

${ }^{2}$ Fadhillah, (2013) Refleksi Terhadap Makna Keadilan Sebagai Fairness Menurut John Rawls Dalam Perspektif Ke-Indonesiaan, Jurnal Hukum Unisma, Februari. Hlm 5.

${ }^{3}$ M.D Mahfud. Penegakan Hukum dan Tata Kelola Pemerintahan Yang Baik, Makalah Mahkamah Konstitusi Republik Indonesia. Hlm 4.
} 
bahwa filsafat hukum memberikan jawaban atas pertanyaan-pertanyaan seperti: Apakah hukum itu sebenarnya? (persoalan adanya tujuan hukum), Apakah sebabnya kita mentaati hukum? (persoalan berlakunya hukum) dan Apakah keadilan keadilan yang menjadi ukuran untuk baik buruknya hukum itu? (persoalan keadilan hukum). Bagaimana hubungan antara hukum dan keadilan?. ${ }^{4}$ Oleh karena itu, filsafat hukum adalah filsafat yang menyelidiki gejala-gejala hukum yang timbul di masyarakat dalam bentuk peraturan-peraturan yang menentukan hak dan kewajiban orang. ${ }^{5}$

Keadilan merupakan unsur yang sangat penting dalam penegakkan hukum dimanapun tempatnya, masyarakat sangat erkepentingan bahwa dalam penegakkan hukum atau pelaksanaan hukum, keadilan harus senantiasa diperhatikan. Intinya dalam melaksanakan penegakkan hukum harus dilakukan dengan adil. ${ }^{6}$ Plato sendiri memberikan definis terkait keadilan. keadilan akan terwujud pada kenyataan dimana setiap orang menjalankan tugasnya masing-masing (merit system based on the proportionality principle) dan tidak suka membuat keributan (social disorder). ${ }^{7}$

${ }^{4}$ Rasjidi L (et all) (2007). Dasar-Dasar Filsafat dan Teori Hukum. Banndung : Citra Aditya Bakti. Hlm 45.

${ }^{5}$ Ibid, h. 196

${ }^{6}$ Mertokusumo. S. (1993) Bab-Bab Tentang Penemuan Hukum, Bandung : Citra Aditya Bakti. Hlm 1-2.

${ }^{7}$ Salam B. (1997) Etika Sosial, Asas Moral Dalam Kehidupan Manusia, Jakarta : Rineka Cipta. Hlm 118.
Dimana seorang lain tidak mencampuri urusan seorang yang lainnya apabila tidak memberikan dampak yang sangat signifikan dalam pemecahan masalah.

Desa asli yang telah ada sejak zaman dahulu memiliki hak dan wewenang untuk mengatur dan mengurus rumah tangganya sendiri. hak dan wewenang untuk menyelenggarakan rumah tangganya sendiri yang biasa disebut hak otonomi. Dalam hal desa, maka desa yang memiliki hak itu disebut sebagai desa otonom. Desa-desa otonom adalah desa yang merupakan subyek-subyek hukum, artinya dapat melakukan tindakan-tindakan hukum. Tindakan-tindakan hukum yang dapat dilakukan antara lain:

1. Mengambil keputusan atau membuat peraturan yang dapat mengikat segenap warga desa atau pihak tertentu, sepanjang menyangkut penyelenggaraan rumah tangganya;

2. Menjalankan pemerintahan desa;

3. Memilih kepala desanya;

4. Memiliki harta benda dan kekayaan sendiri;

5. Memiliki tanah sendiri;

6. Menggali dan menetapkan sumbersumber keuangan sendiri;

7. Menyusun anggaran penerimaan dan pengeluaran keuangan desa;

8. Menyelenggarakan gotong royong;

9. Menyelenggarakan peradilan desa; 
10. Menyelenggarakan usaha lain demi kesejahteraan masyarakat desa ${ }^{8}$

Dalam perjalanan sejarah sendiri bisa terjadi dan memang ada terjadi, perubahanperubahan bobot otonomi desa sedemikian rupa, sehingga pada suatu waktu bisa diketemukan satuan-satuan masyarakat yang tidak lagi memenuhi seluruh atau sebagian unsur-unsur otonomi desa, atau dengan perkataan lain, seluruh atau sebagian masyarakat hukum adat tidak berfungsi lagi pada umumnya hal tersebut dipengaruhi oleh beberapa faktor sebagai berikut:

1. Penduduk suatu desa semakin heterogen sehingga sukar ditentukan, hukum adat mana yang dapat berlaku didalam masyarakat yang bersangkutan;

2. Aspek-aspek kehidupan masyarakat yang selama ini (cukup) diselenggarakan oleh desa, oleh salah satu dan alasan lain berdasarkan ketentuan yang lebih tinggi, diselenggarakan oleh pemerintahan yang lebih atas;

3. Kegiatan ekonomi sekunder dan tersier semakin besar, sehingga diperlukan fisik dan tata masyarakat desa yang bersangkutan menurut norma-norma yang lebih tinggi;
4. Sumber-sumber pendapatan diambil alih oleh pemerintah yang lebih tinggi.

Perihal melaksanakan pemerintahannya, Kepala Desa bersama dengan Badan Permusyawaratan Desa (BPD) menetapkan peraturan desa (Vide: Pasal 55 ayat (3) PP No. 72 Tahun 2005). Akan tetapi peraturan desa tersebut hanya merupakan penjabaran lebih lanjut dari peraturan perundang-undangan yang lebih tinggi, bukan merupakan instrumen dalam rangka memperdayakan masyarakat desa untuk mencapai kesejahteraan dan kemakmuran. Untuk itu perlu diadakannya reformasi pemerintahan desa yang dimaksudkan untuk memperbaharui dan memperkuat unsurunsur demokrasi dalam bentuk dan susunan pemerintahan desa. Sebagaimana pendapat sebagai berikut:

"Masyarakat desa dan pemerintahan desa,
sehingga pemerintah desa dalam segala
keputusannya dan tindakannya selalu
mengutamakan kepentingan dan aspirasi
masyarakat desa tanpa melupakan
kepentingan Negara Kesatuan RI dalam
rangka persatuan dan kesatuan bangsa
(Bhinekka Tunggal Ika). Disamping itu
masyarakat desa wajib mendukung
pemerintahannya dengan mentaati
keputusan-keputusan serta mentaati
tindakan-tindakannya yang demokratis
dan sekaligus dapat pula mengkoreksi

\footnotetext{
${ }^{8}$ Ndraha. T. (1981). Dimensi-Dimensi Pemerintahan Desa. Bina Aksara. Hlm 17-18.
} 
tindakan-tindakan yang merugikan masyarakat". 9

Secara konsep kewenangan, berdasarkan Pasal 200-Pasal 202 UU No 32 Tahun 2004 jo. UU No. 23 Tahun 2014 Tentang Pemerintahan Daerah, disebutkan bahwa pemerintahan desa terdiri dari 2 (dua) unsur, yaitu pemerintah desa yang terdiri dari Kepala Desa dan perangkat desa dan Badan Permusyawaratan Desa (BPD). Adapun tugas dan wewenang kepala desa menurut Pasl 14 ayat (1) dan (2) PP No. 72 Tahun 2005 menyatakan bahwa:

(1) Kepala Desa mempunyai tugas menyelenggarakan urusan pemerintahan, pembangunan, dan kemasyarakatan;

(2) Dalam menjalankan tugas sebagaimana dimaksud pada ayat (1) Kepala Desa Mempunyai wewenang;

a. Memimpin penyelenggaraan pemerintahan desa berdasarkan kebijakan yang ditetapkan bersama BPD;

b. Mengajukan rancangan peraturan desa;

c. Menetapkan peraturan desa yang telah mendapat persetujuan bersama BPD;

d. Menyusun dan mengajukan rangcangan peraturan desa

\footnotetext{
${ }^{9}$ Widjaja. A.W. (1996) Pemerintahan Desa Dan Administrasi Desa Menurut UU No. 5 Tahun 1979 (sebagai tinjauan), Jakarta : Raha Grafindo Persada.
}

mengenai APB Desa dan ditetapkan bersama BPD;

e. Membina kehidupan masyarakat desa;

f. Membina perekonomian desa;

g. Mengkoordinasikan pembangunan desa secara partisipatif;

h. Mewakili desanya didalam dan di luar pengadilan dan dapat menunjuk kuasa hukum untuk mewakili sesuai dengan peraturan perundang-undangan; dan

i. Melaksanakan wewenang lain sesuai dengan peraturan perundangundangan.

Sedangkan berkaitan dengan kewajiban yang harus dilaksanakan Kepala Desa menurut ketentuan Pasal 15 ayat (1) dan ayat (2) PP No. 72 Tahun 2005 menyebutkan:

(1) Dalam melaksanakan tugas dan wewenang sebagaimana dimaksud dalam Pasal 14, Kepala Desa mempunyai kewajiban:

a. Memegang teguh dan mengamalkan Pancasila, melaksanakan Undang-Undang Dasar Negara Republik Indonesia Tahun 1945 serta mempertahankan dan memelihara keutuhan Negara Kesatuan Republik Indonesia;

b. Meningkatkan kesejahteraan masyarakat; 
c. Memelihara ketentraman dan ketertiban masyarakat;

d. Melaksanakan

kehidupan demokrasi;

e. Melaksanakan prinsip tata pemerintahan desa yang bersih dan bebas dari Kolusi, Korupsi dan Nepotisme;

f. Menjalin hubungan kerja dengan seluruh mitra kerja pemerintahan desa;

g. Mentaati dan menegakkan seluruh peraturan perundang-undangan;

h. Menyelenggarakan administrasi pemerintahan desa yang baik;

i. Melaksanakan dan mempertanggung jawabkan pengelolaan keuangan desa;

j. Melaksanakan urusan yang menjadi kewenangan desa;

k. Mendamaikan perselisihan masyarakat di desa;

1. Mengembangkan pendapatan masyarakat dan desa;

m. Membina, mengayomi dan melestarikan nilai-nilai sosial, budaya dan adat istiadat;

n. Memberdayakan masyarakat dan kelembagaan di desa;dan

o. Mengembangkan potensi sumber daya alam dan melestarikan lingkungan hidup.

(2) Selain kewajiban sebagaimana dimaksud pada ayat (1) Kepala Desa mempunyai kewajiban untuk memberikan laporan penyelenggaraan pemerintahan desa kepada Bupati/Walikota, memberikan laporan keterangan pertanggung jawaban kepada BPD, serta menginformasikan laporan penyelenggaraan pemerintahan desa kepada masyarakat.

Pengertian mengenai kewajiban Kepala Desa untuk menyelesaikan perselisihan masyarakat, perlu dijabarkan lebih lanjut dengan merujuk pada suatu konsep dimana Kepala Desa juga dapat berperan sebagai penengah dalam setiap permasalahan yang ada. Permasalahan tersebut tidak hanya dibatasi dalam ruang lingkup keperdataan saja antara seseorang dengan seseorang lainnya, akan tetapi permasalahan tersebut dapat pula ditinjau dari segi hukum lain. Terkait dengan persoalan yang telah dikemukakan diatas, penyelesaian suatu permasalahan dengan cara yang lebih efektif dan efisien dianggap perlu sebagai mekanisme kontrol Kepala Desa terhadap dinamika masyarakatnya itu sendiri. Keterlibatan Kepala Desa dalam menyelesaikan konflik dalam masyarakat desa menjadikan penulis tertarik untuk mengkajinya dalam penelitian hukum ini. Berdasarkan latar belakang masalah di atas, maka pertanyaan hukum/ isu hukum yang muncul kemudian adalah: Apa hakikat penyelesaian perkara di luar pengadilan yang dilakukan oleh Kepala Desa terhadap masyarakat desanya? Dan Bagaimana 
reformulasi kebijakan hukum dalam undangan (statute approach) dan pendekatan mengimplemetasikan hakikat penyelesaian konseptual (conseptual approach). Peter suatu permasalahan di luar pengadilan?.

\section{Metode Penelitian}

Penelitian ini menggunakan beberapa mahmud Marzuki mengatakan bahwa pendekatan yang digunakan dalam penulisan diatas antara lain:" "Statute Approach pendekatan sebagai satu kesatuan yang utuh, adalah Pendekatan Perundang-undangan yaitu pendekatan perundang-undangan yang dilakukan dengan menelaah semua (statute approach), pendekatan historis undang-undang dan regulasi yang bersangkut (historical approach), dan pendekatan konseptual (conceptual approach) ${ }^{10}$, serta pendekatan kasus (case approach). Terkait dengan penelitian ini pendekatan perundangundangan digunakan untuk mencari ratio Legis dasar ontologis Peraturan perundang undangan terkait dengan penyelesaian suatu permasalahan yang terjadi. Pendekatan konseptual digunakan karena dalam penelitian ini penulis ingin mengetahui beberapa konsep diantaranya; 1) penyelesaian perkara di luar pengadilan baik itu dalam lapangan hukum perdata, pidana, adat, dll.

Pendekatan historis digunakan dalam penelitian ini karena ingin memahami filosofi aturan hukum dari waktu ke waktu utamanya terkait dengan politik hukum pidana. Sesuai dengan tipe penelitian, pendekatan konseptual (conceptual approach) diberikan bobot lebih besar dibandingkan pendekatan lain. Pendekatan Masalah yang digunakan dalam penelitian hukum ini adalah pendekatan perundang-

\footnotetext{
${ }^{10}$ Marzuki M. (2009). Penelitian Hukum. Jakarta :
} Kencana Prenada Media Group. Hlm 93. paut dengan isu hukum yang sedang ditangani. Conseptual Approach pendekatan konseptual beranjak dari pandanganpandangan para ahli". Dengan demikian perlu mencari Ratio Legis dan dasar ontologi lahirnya undang-undang, sehingga peneliti mampu memahami kandungan filosofis yang ada di belakang undang-undang, dan menyimpulkan mengenai ada tidaknya benturan filosofi antara undang-undang dengan isu yang dihadapi. ${ }^{12}$ Dengan pendekatan konseptual (Conseptual Approach), peneliti akan menemukan ide-ide yang melahirkan pengertian-pengertian hukum, konsep-konsep hukum dan asas-asas hukum yang relevan dengan isu yang diahadapi. $^{13}$

\section{Analisis dan Pembahasan}

Hukum sebagai kaidah yang mengatur kehidupan manusia harus dapat digunakan sebagai sarana untuk mencapai keadilan, sehingga pertimbangan rasional dapat menerima kehadiran hukum sebagai tatanan nilai-nilai dan norma-norma yang ada dan berkembang dalam

\footnotetext{
${ }^{11}$ Ibid. Hlm 133.

${ }^{12}$ Ibid. Hlm 94.

${ }^{13}$ Ibid. HIm 95.
} 
masyarakat sebagai upaya untuk mewujudankan keteraturan sosial dan tidak membenarkan segala bentuk kekerasan yang terjadi dalam masyarakat. Oleh karena itu, hukum merupakan unsur penting dalam mengatur kehidupan bermasyarakat berbangsa dan bernegara.

Mewujudkan hal tersebut, maka hukum harus menjadi perwujudan dari 4 (empat) sistem norma yang berlaku dalam kehidupan masyarakat tersebut yaitu norma agama, norma kesusilaan, norma kesopanan dan norma hukum itu sendiri. Sejalan dengan hal ini, Meuwissen sebagaimana dikutip Budiono $^{14}$ berpandangan bahwa hukum merupakan tatatan yang berupaya mempengaruhi perilaku manusia sehingga pemenuhan kebutuhan-kebutuhan dan keperluan-keperluannya dilakukan dengan cara proporsional berdasarkan moral atau adil serta prinsip-prinsip umum yang dibenarkan.

Pergeseran pemahaman tentang hukum sebagai kaidah dan unsur penting sebagai sarana mencapai keadilan, Meuwissen juga mengemukakkan ada empat momen penting yang menandai hukum yaitu, ${ }^{15}$ Pertama momen formal-normatif yang menempatkan hukum sebagai tatanan formal yang bertujuan menegakkan perdamaian, ketertibaan, harmoni dan kepastian hukum. Kedua momen formal-faktual yang mencerminkan hukum sebagai gejala

\footnotetext{
${ }^{14}$ Kusumohamidjojo B. (1996), Ketertibaan Yang Adil, Jakarta : Grassindo. Hlm 211.

${ }^{15}$ Ibid
}

kekuasaan yang dapat mempengaruhi sikap dan perilaku manusia. Ketiga momen material-normatif dengan menitikberatkan bahwa hukum harusnya memuat aspek etis. Keempat momen material-faktual yang mensyaratkan bahwa hukum pada prinsipnya berkaitan dengan keperluan-keperluan manusia akan hukum itu sendiri.

Seiring dengan meningkatnya tingkat pendidikan masyarakat dan kesadaran hukumnya, serta pandangan-pandangan kritis dalam upaya mengembangkan jiwa hukum (volkgeist) dan jiwa keadilan dalam masyarakat maka konsep keadilanpun mengalami pergeseran menuju ke arah keadilan yang lebih mengutamakan manfaat bagi para pihak, bukan sekedar keadilan hukum. Hal ini di dasarkan pada pandangan bahwa setiap kelompok masyarakat selalu memiliki problem sebagai akibat dari adanya perbedaan yang ideal dan yang aktual, antara yang standar dan yang praktis, antara yang seharusnya dengan yang diharapkan untuk dilakukan dan apa yang ada dalam kenyataan. Standar dan nilai-nilai kelompok dalam masyarakat mempunyai variasi sebagai faktor yang menentukan tingkah laku individu. Penyimpangan terhadap nilai-nilai yang ada dalam masyarakat membawa kesenjangan perilaku dan mengganggu ketertiban dalam masyarakat. ${ }^{16}$

\footnotetext{
${ }^{16}$ Soemitro. R.H. (1985). Beberapa Masalah Dalam Sudi Hukum Dan Masyarakat,Bandung : Remaja Karya. HIm 53.
} 
Menurut Pasal 27 ayat (1) UndangUndang Dasar Negara Republik Indonesia Tahun 1945 (UUD NRI 1945), yang menyatakan, bahwa : "Segala warga negara bersamaan kedudukannya di dalam hukum dan pemerintahan dan wajib menjunjung hukum dan pemerintahan itu dengan tidak ada kecualinya" Dalam hal ini Negara berkomitmen bahwa setiap warga negara harus di perlakukan baik dan adil sama kedudukannya di dalam hukum, juga, perikemanusiaan sebagai sendi nilai falsafah negara Pancasila menjiwai seluruh keberadaan hukum di negara Indonesia, mulai dari UUD NRI tahun 1945 hingga kepada peraturan perundang-undangan ke bawahnya.

Melihat hal dalam pemerintahan desa, sebagai suatu daerah yang dianggap penting, pada zaman kolonial dahulu pun daerah pedesaan tersebut merupakan bagian dari adanya suatu peradilan pribumi yang ada di Jawa dan Madura, atau peradilan daerah swapraja di luar Jawa dan Madura. Hakim desa berhak untuk memeriksa berbagai perkara yang menurut hakim adat termasuk didalam bagian yurisdiksinya. Kompetensi dari hakim desa diatur sedemikian rupa, sehingga tercegah kemungkinan timbulnya sengketa yurisdiksi dengan hakim gubernemen ataupun hakim agama. Karena menilik dari adanya fungsi hakim, menurut Ter Har adalah sebagai berikut: "Eerst en voornaamste oogmerk van de beroepsrechter, die zoekt naar regelen van gewoonterecht, waarmede hij zijn uitspraak in het hun voogrgeleg de geschil zal kunnen motiveren is, moet althans zijn: het vinden van concrete beslissingen in vroegere gevallen" yang apabila tidak dapat mengambil suatu keputusan mengenai perkara yang ada maka hakim melakukannya dengan pertimbangan asas-asas dan sistem hukum adat yang berlaku sebagaimana penjelasan berikut: "Kent de rechter geen vroegere beslissingen in gevallen met gelijke relevante feiten of bleken die beslissingen niet houdbaar, dan moet hij nietemin een beslissing nemen, welke naar zijn besteweten als rechtsbeslissing en dus als rechtsregel te gelden heeft in het millieu, waarin hij rechtspreekt. Om die beslissing te vinden moet hij zich doordringen van het rechtsstelsel in zijn geheel, moet hij de sociale werkelijkheid kennenen de eisen der menselijkheid". ${ }^{17}$

Apabila ada keserasian antara ketentraman dengan ketertiban, akan tercapailah suatu kedamaian dalam masyarakat. Dengan demikian, diharapkan kepala-kepala desa dapat membina kedamaian yang berarti tidak adanya suatu kekangan terhadap kebebasan serta tidak ada suatu gangguan terhadap ketertiban. Kedamaian tersebut sebenarnya merupakan tujuan hukum yang paling hakiki yang dapat

\footnotetext{
${ }^{17}$ Haar. B,T. (1930) Het Adatproces Der Inlanders. Amsterdam : A.H Kruyt, Uitgever
} 
dicapai melalui kepastian hukum dan persamaan hukum. Dengan demikian, inti fungsi Kepala Desa adalah menerapkan hukum sebagai sarana untuk mengendalikan dan memperbaharui masyarakat di desanya.

Kebijakan hukum dalam mengimplemetasikan hakikat penyelesaian suatu permasalahan di luar pengadilan Oleh Kepala Desa.

Secara tradisional kedudukan dan peranan Kepala masyarakat Hukum Adat adalah sama dengan Kepala Adat. Oleh karena Kepala Adat adalah sama dengan Kepala Masyarakat Hukum Adat. Seorang Kepala Masyarakat Hukum Adat mempunyai beberapa kewenangan sebagai berikut:

1. Tindakan-tindakan mengenai urusan tanah berhubungan dengan adanya pertalian yang erat antara tanah dengan persekutuan (golongan manusia) yang menguasai tanah tersebut;

2. Penyelenggaraan hukum sebagai usaha untuk mencegah adanya pelanggaran hukum (preventieve rechtszorg), supaya hukum dapat berjalan dengan semestinya; dan

3. Penyelenggaran hukum sebagai pemulihan hukum, setelah hukum itu dilanggar (represieve rechtszorg). ${ }^{18}$

Seorang Kepala Desa yang sebagai pemimpin dianggap adil, apabila dirinya dapat menjaga harmoni dari pola interaksi

\footnotetext{
${ }^{18}$ Soepomo. (1977) Bab-Bab Tentang Hukum Adat, Jakarta : Pradnya Paramita. Hlm 44.
}

sosial, yang merupakan inti proses sosial. Masyarakat akan puas apabila terwujud bersatunya warga masyarakat dengan pemimpinnya. Pemimpin harus dapat menyesuaikan diri dengan perkembangan masyarakat. Disamping itu seorang penguasa harus memiliki keberanian, kebijaksanaan, dan keadilan. Kepala Desa dalam hal ini masuk dalam kategori eksekutif dalam Trias Politica, berkewajiban untuk menjalankan sesuatu peraturan yang sebelumnya telah dibuat oleh lembaga legislatif desa (Badan Permusyawaratan Desa).

Selama ini Peraturan Desa (Perdes) yang dibuat hanya sampai pada tahapan turunan daripada peraturan perundangundangan yang ada. Padahal dengan menyandang status sebagai Desa yang dirasa begitu istimewa di Indonesia, Desa harusnya mampu membuat suatu kemandirian dan inovasi baru dalam rangka memberikan keamanan dan kenyamanan serta ketertiban bagi warga masyarakatnya. Pelaksanaan penyelesaian sengketa secara alternatif (non litigasi) perlu dilakukan sebagai bentuk kemandirian dan keistimewaan desa dan secara tidak langsung akan lebih mengefesiensikan suatu perkara agar tidak semakin menumpuk di pengadilan.

Hal semacam ini dalam keilmuan hukum perdata dikenal dengan sebutan Alternative Dispute Resolution (ADR), dan dalam keilmuan hukum pidana dikenal 
sebagai "mediasi penal". Walaupun pada umumnya penyelesaian sengketa di luar pengadilanhanya ada dalam sengketa keperdataan, namun dalam prakteknya sering juga kasus pidana diselesaikan melalui jalur non litigasi melalui berbagai diskresi Aparat Penegak Hukum ataupun melalui musyawarah/perdamaian atau lembaga penyelesaian sengketa yang ada di masyarakat dapat berupa musyawarah keluarga; musyawarah desa; musyawarah adat; dsb. Praktek penyelesaian perkara (khusunya perkara pidana) semacam ini yang diselesaikan diluar pengadilan untuk saat ini belum ada suatu landasan hukum formiilnya, sehingga sering terjadi suatu kasus yang secara informal telah ada penyelesaian damai (walaupun melalui mekanisme hukum adat), namun tetap saja diproses ke pengadilan sesuai hukum yang berlaku. ${ }^{19}$ Untuk itulah penyelesaian sengketa oleh Kepala Desa dapat dikategorikan sebagai suatu diskresi darinya dalam rangka pelayanan publik bagi warga masyarakatnya.

Mengenai Kedudukan Kepala Desa sebagai hakim perdamaian juga tentunya memiliki sedikit permasalahan terkait dengan dalam bagian domain keilmuan hukum (pidana, perdata, administrasi) manakah yang paling tepat untuk membahas pembahasan kali ini mengingat bahwa sebagai sesama

\footnotetext{
${ }^{19}$ Arief B.N. (2007) Aspek Kebijakan Mediasi Penal Dalam Penyelesaian Sengketa Di Luar Pengadilan. Semarang : Seminar Nasional, Program Doktor Ilmu Hukum Universitas Diponegoro. Hlm 2.
}

bagian dari hukum publik, baik Hukum Pidana dan HAN memiliki kesamaan asas, diantaranya asas legalitas. Asas ini menjadi dasar masyarakat dan pemerintah melakukan tindakan hukum. Perluasan yang terjadi diantara keduanya sebagai upaya adaptasi dengan perkembangan masyarakat tentunya juga memiliki dampak satu sama lain dan jika hal ini tidak dibicarakan secara mendalam maka akan timbul "grey area" diantara keduanya. Hal ini salah satunya karena keistimewaan hukum pidana yang kaidahnya ada di bagian hukum lain, dan sanksinya bisa diterapkan di hampir semua cabang ilmu hukum. Hadirnya "grey area" ini juga disebabkan luasnya cakupan HAN yang sampai saat ini batasannya masih belum ditentukan. Penentuan batasan ini sebenarnya bisa dibahas secara mendalam, dan kemudian dituangkan secara tertulis sebagai acuan "hukum" itu sendiri.

Bagaimanapun bentuknya Kepala Desa yang berperan sebagai hakim perdamaian bagi masyarakatnya merupakan suatu sarana untuk membuat suatu hukum yang mengatur hak dan kewajiban subyek hukum agar masing-masing menjalankan kewajibannya dengan baik dan mendapatkan haknya secara wajar. Disamping itu, hukum juga berfungsi sebagai instrumen perlindungan bagi subyek hukum itu sendiri. ${ }^{20}$

\footnotetext{
${ }^{20}$ Arief. B.N. (2002) Bunga Rampai Kebijakan Hukum Pidana. Bandung : Citra Aditya Bakti, 2002. Hlm 97.
} 
Dalam dunia hukum, ada tiga bentuk penuangan keputusan norma hukum, yaitu keputusan yang bersifat mengatur (regelling) menghasilkan peraturan (regels) ; keputusan hukum yang bersifat menentukan atau menetapkan sesuatu secara administratif negara (beschikkings); keputusan yang bersifat menghakimi sebagai hasil proses peradilan (adjudication) menghasilkan putusan (vonnis). Disamping itu ada pula yang dinamakan sebagai beleidsregel atau aturan kebijakan (policy rules) yang sering disebut quasi pengaturan, seperti petunjuk pelaksanaan, surat edaran, instruksi, dan sebagainya yang tidak dapat dikategorikan peraturan tetapi isinya bersifat mengatur juga. $^{21}$

Adanya kebijakan ini tidak serta merta diterapkan secara kaku sehingga menyebabkan birokrasi semakin lamban, termasuk proses penegakan hukum. Oleh karenanya, guna menjamin ruang gerak bagi pejabat dalam menjalankan tugasnya diakui adanya prinsip frijsermessen yang memungkinkan Kepala Desa mengembangkan dan menetapkan sendiri beleid-regels atau policy rules secara internal dengan bebas dan mandiri untuk menjalankan tugas jabatan yang dibebankan oleh peraturan yang sah. ${ }^{22}$ Indroharto menerjemahkannya dalam dua aspek pokok,

\footnotetext{
${ }^{21}$ Asshiddiqie J. (2007) Pokok-Pokok Hukum Tata Negara Indonesia, Pasca Reformasi. Jakarta : Buana Ilmu Populer. Hlm 209.

${ }^{22}$ Jimly Asshiddiqie, Op Cit. Hlm 156.
}

yakni kebebasan menafsirkan mengenai ruang lingkup wewenang yang dirumuskan dalam peraturan dasar wewenangnya (kebebasan menilai secara objektif), dan kebebasan menentukan sendiri dengan cara bagaimana dan kapan wewenang yang dimiliki administrasi negara dilaksanakan (kebebasan menilai secara subjektif). Hal ini coba dipaparkan lebih lanjut oleh P.J.P dan dikutip Ridwan HR, sebagai berikut ${ }^{23}$ :

"beleidsregels zijn algemene regels die
een bestuursinstantie stelt omtrent de
uitoefening van een bestuurbevoegdheid
jegens de burgers of een andere
bestuursinstantie en voor welke
regelstelling de grondwet noch de
formele wet direct of indirect een
uitdrukkelijke gronslag biedien.
Beleidsregels berusten dus niet op een
bevoegdheid tot wetgeving-en kunnen
daarom ook geen algemen verbindende
voorschriften zijn-maar op een
bestuursbenoedgheid van een
bertuursorgaan en betreffen de
uitoefening vandie bevoegdheden"

(Peraturan kebijakan adalah peraturan umum yang dikeluarkan oleh instransi pemerintah berkenaan dengan pelaksanaan wewenang pemerintah terhadap warga negara atau terhadap instansi pemerintah lainnya dan pembuatan peraturan tersebut tidak memiliki dasar yang tegas dalam UUD dan undang-undang formal baik langsung maupun tidak langsung. Artinya peraturan kebijakan tidak didasarkan pada kewenangan pembuatan undang-undang dan oleh karena

\footnotetext{
${ }^{23}$ Ibid. Hlm 177.
} 
itu tidak termasuk peraturan perundang undangan yang mengikat umum tetapi dilekatkan pada wewenang pemerintahan suatu organ administrasi negara dan terkait dengan pelaksanaan kewenangannya)

Peraturan kebijakan ini oleh Bagir Manan dalam Ridwan HR dicirikan yaitu ${ }^{24}$

- Peraturan kebijakan bukan merupakan peraturan perundang-undangan.

- Asas pembatasan dan pengujian terhadap peraturan perundangan tidak dapat diberlakukan pada peraturan kebijakan.

- Peraturan kebijakan tidak dapat diuji secara wetmatigheid.

- Peraturan kebijakan dibuat berdasarkan freies Ermessen dan ketiadaan wewenang administrasi bersangkutan membuat peraturan perundangan.

- Pengujian terhadap peraturan kebiijakan lebih diserahkan pada doelmatigheid dan karena itu batu ujiannya adalah asas umum pemerintahan yang baik.

- Dalam praktek diberi format dalam berbagai bentuk jenis aturan seperti keputusan, instruksi, surat edaran, pengumuman, dll.

\section{Kesimpulan}

Penyelesaian suatu permasalahan hukum yang terjadi dalam masyarakat pedesaan tidak harus diselesaikan secara konvensional (melalui pengadilan). Disatu sisi desa merupakan suatu entitas masyarakat yang diberi keistimewaan oleh UUD NRI 1945 untuk mengatur jalannya rumah tangganya sendiri. Kepala Desa yang sebagai pemimpin dianggap adil, apabila dirinya dapat menjaga harmoni dari pola interaksi sosial, yang merupakan inti proses sosial. Masyarakat akan puas apabila terwujud bersatunya warga masyarakat dengan pemimpinnya yang juga sebagai hakim di tengah-tengah mereka.

Penyelesaian suatu permasalahan yang terjadi di Desa dengan menempatkan Kepala Desa sebagai hakim perdamaian merupakan suatu bentuk diskresi/kebijakan dari lembaga eksekutif dalam rangka mewujudkan pelayanan publik bagi masyarakat. Dengan kata lain dikarenakan hal tersebut merupakan suatu diskresi, sudah barang tentu mengikuti peraturan perundang-undangan yang menyatakan batasan-batasan akan hal tersebut.

Adapun saran yang dapat diberikan yaitu Kepala Desa diberi kewenangan untuk menyelesaikan perkara pidana yang masih dapat diselesaikan oleh warga masyarakatnya secara kekeluargaan. Aparat Penegak Hukum (Polisi, Kejaksaan, Hakim) sebaiknya tidak mencampuri urusan yang sudah terdapat mekanisme penyelesaian secara intern di desa. Mengingat penyelesaian perkara tersebut menggunakan asas-asas dan hukum

\footnotetext{
${ }^{24}$ Ibid. Hlm. 179.
} 
adat yang sudah berlaku dan melekat sejak lama.

Direvisinya kembali UU Desa dengan memasukkan pengaturan yang jelas mengenai Kedudukan Kepala Desa dengan menambahkan kewenangannya sebagai Hakim Perdamaian dengan sistem hukum adat di tengah masyarakatnya, mengingat Peradian Adat untuk saat ini sudah tidak ada lagi. Disamping itu Kepala Desa dalam melaksanakan kewenangannya sebagai hakim perdamaian menjadi memiliki legitimasi hukum yang jelas, karena bentuk diskresi yang ada selama ini sangat rawan untuk disalahgunakan.

\section{DAFTAR PUSTAKA}

Arief, Barda Nawawi (2002) Bunga Rampai Kebijakan Hukum Pidana, Cetakan Kedua edisi revisi, Bandung : Citra Aditya Bakti

Arief, Barda Nawawie (2007) Aspek Kebijakan Mediasi Penal Dalam Penyelesaian Sengketa Di Luar Pengadilan. Semarang : Seminar Nasional, Program Doktor Ilmu Hukum Universitas Diponegoro.

Asshiddiqie, Jimly (2007) Pokok-Pokok Hukum Tata Negara Indonesia, Pasca Reformasi. Jakarta : Buana Ilmu Populer.

Ashiddiqie, Jimmly (2015) Pengantar Ilmu Hukum Tata Negara. Jakarta : Raja Grafindo.
Dirdjosiswono. (1994) Pengantar Ilmu Hukum. Jakarta : Raja Grafindo Persada.

Adhillah. (2013) Refleksi Terhadap Makna Keadilan Sebagai Fairness Menurut John Rawls Dalam Perspektif KeIndonesiaan, Unisma : Jurnal Hukum.

Haar, B Ter Bzn. (1930). Het Adatproces Der Inlanders, Amsterdam : A.H Kruyt, Uitgever.

Hutchinson, Terry. (2002) Researching and Writing in Law. Sidney Australia : LAW BOOK Co.

Kusumohamidjojo, Budiono. (1996). Ketertibaan Yang Adil, Jakarta : Grassindo.

Marzuki, Peter Mahmud. (2009) Penelitian Hukum, Jakarta : Kencana Prenada Media Group.

Mertokusumo, Sudikno. (1993) Bab-Bab Tentang Penemuan Hukum. Bandung : Citra Aditya Bakti.

Rasjidi, Lili dan Ira Thania rasjidi. (2007). Dasar-Dasar Filsafat dan Teori Hukum. Bandung : Citra Aditya Bakti.

Salam, Burhanudin. (1997) Etika Sosial, Asas Moral Dalam Kehidupan Manusia. Jakarta : Rineka Cipta.

Soemitro, Ronny Hanitijo. (1985). Beberapa Masalah Dalam Sudi Hukum Dan Masyarakat, Bandung : Remaja Karya.

Soepomo. (1997) Bab-Bab Tentang Hukum Adat, Jakarta : Pradnya Paramita.

Widjaja, A.W.,(1996) Pemerintahan Desa Dan Administrasi Desa Menurut UU No. 5 Tahun 1979 (sebagai tinjauan), Jakarta : Raha Grafindo Persada. 